\title{
Challenges in the private forest sector of Canada ${ }^{1}$
}

\author{
by Gilbert G. Paillé2
}

The author describes what he sees as the five biggest challenges facing stakeholders of the Canadian forest sector at the beginning of the XXI century. The first is building strong political support for forest development through information and education at a time when public opinion is opposing it; the second is prioritizing the development of private forests by reversing the northerly direction historically followed by forest activities in Canada; the third is defining sustainable forest development and implementing it on a stable land base, following sound forest practices codes and certification standards, with full public involvement; the fourth is convincing forest land owners to invest more attention, time, effort and even money in growing more wood and offering more services on their properties in order to fulfill an increasing demand; and the last challenge is convincing all levels of government to each support their share of the forest activities to ensure a sustained flow of benefits to forest land owners, industrial shareholders, and society as a whole.
L'auteur décrit ce qu'il considère comme étant les cinq plus importants défis auxquels les intervenants du secteur forestier canadien devront faire face au début du XXIe siècle. Le premier défi consiste en l'élaboration d'appuis politiques solides en matière de développement forestier par l'entremise de l'information et de l'éducation à un moment où l'opinion publique s'y oppose; le deuxième défi est constitué du développement prioritaire des forêts privées par le renversement de la direction prise vers le nord par les activités forestières au Canada; le troisième défi fait état de la définition du développement forestier durable et de son implantation sur un domaine forestier stable, accompagné de codes de saines pratiques forestières et de normes de certification et comprenant l'entière participation du public; le quatrième défi vise à convaincre les propriétaires des terres forestières à investir plus d'attention, de temps, d'efforts et même d'argent pour accroître le volume de bois et offrir plus de services sur leurs propriétés de façon à répondre à la demande sans cesse croissante; et le cinquième défi sera de convaincre tous les niveaux de gouvernement à appuyer entre eux leurs parts d'activités forestières afin d'assurer un flot soutenu de bénéfices aux propriétaires des terres forestières, aux intervenants du secteur industriel et à la société en général.

\section{Introduction}

I am glad to have been invited to participate in this National Forest Congress because it gives me the opportunity to speak to the members of the Coalition, and to all stakeholders of the forest sector assembled here to adopt a fourth forest strategy for Canada.

My plan is to describe what I view as being some of the major challenges now facing the private forest sector of Canada, and to identify some actions needed to turn these situations around. These actions are not all part of the framework for action presented under the strategic direction pertaining to private woodlots, but could also be found elsewhere in the strategy. I hope that they can be implemented before we assemble again to prepare a fifth National Forest Strategy in 2003.

\section{Building a Strong Political Support for Forest Development}

\section{"Sustainable development must rest on political will" (The Brundtland Report (WCED 1987))}

I believe that the biggest challenge now facing the forest sector of Canada is to find ways and means to get strong political support behind forest development and the forest industry. The trend now seems to be going in the opposite direction.

As you well know, wood is a basic commodity for all human beings. Its use is therefore likely to increase with the world population, which has almost 6 billion people now, and is growing at the rate of $1.9 \%$ a year (or 275,000 human

\footnotetext{
${ }^{1}$ Paper presented at the National Forest Congress, 30 April 1998, Ottawa, Canada. ${ }^{2}$ President and Chief Executive Officer, Forest Engineering Research Institute of Canada, Pointe-Claire, Quebec.
}

beings a day), to double by year 2050 . The demand for wood will thus increase tremendously in the future, within each country and from abroad.

The demand for cash will also increase in order for many governments to be able to reimburse their enormous debts, and to provide social services (health, education, transportation) required by most populations.

Canada is a forest nation currently supplying wood to satisfy the demand of its population and of its forest industries, and exporting its surplus production to a large number of countries. This economic activity, based on its most abundant renewable natural resource, does contribute now to the balance of trade for more than $\$ 32$ billion a year (Resources Naturelles Canada 1997), helping every Canadian to maintain one of the highest standards of living in the whole world.

While this is taking place, however, the demand for environmental protection and for reserved green spaces is also increasing. As the population increases, people need more forested areas for meditation, more breathing space, more quietness.

Thus, today, the general public in most provinces of Canada favor the creation of an ever increasing number of recreation areas, ecological and wildlife reserves, old-growth sanctuaries and national parks. It is in fact strongly supporting all kinds of non-economic uses of green spaces, regardless of the impact that they have on forest owners, and on the forest industry.

Furthermore, this attitude is favored by many environmental movements which make people believe that almost any type of intervention in the forest landscape is detrimental, in particular the removal of trees (May 1998). The propaganda is well orchestrated by powerful organizations, some of which are sinking their roots in countries with which Canada is competing for 
billion-dollar shares of the forest product markets of the world.

These forces in favor of environmental protection are making forest development more and more difficult, and more and more costly. So much so that in many regions of the country, investments in the forest sector have already decreased substantially and in some cases have been halted by insecurity; thus, the competitiveness of the Canadian forest industry is being threatened.

The reversal of this trend represents a tremendous challenge for many reasons.

One, the amount of effort and money spent by "green movements" around the globe to preach their gospel seems to be far larger than what other forest stakeholders spend preaching the virtue of big common sense and sustainable forest management. The fastest way to convince yourself that this is the case is to enter the World Wide Web, or simply to ask your children.

Two, in this age of computerized decision-making and virtual reality, most people do not realize how much they still depend on wood and on woodlands for their daily living and well being, and what the satisfaction of their most basic needs implies.

Three, the reversal of the trend is not easy because most people believe strongly that "what they see is what they get." When they look at Canadian forests these days, especially from fast moving cars on black top roads, they do not always get the feeling that good husbandry and tender loving care have been given to easily accessible private forest lands (Paillé 1997).

How is it possible to turn this situation around? Basically, it is through sound public information and education of the younger generations:

i. People must be made more aware of the large proportion of their needs that is satisfied with forest resources, and of the implications of this situation.

ii. People must be made aware that more intensive silviculture must be practiced in order to produce more wood fiber, if Canada is to satisfy an increasing demand on a sustained basis.

iii. People must be made aware that it is much safer ecologically to use forest products than any substitute material made of non-renewable resources, such as steel, aluminum and plastics.

iv. People must be made aware that the purpose of forestry is not to destroy forest lands, but to make them produce as much wood as possible while favoring other values, and that the interventions needed to achieve that goal are not incompatible with most other human activities.

Massive long-term programs of popular education, launched immediately to gain strong public support for sustainable forest development must be part of all solutions. Such programs should be financed by all forest stakeholders, and actively supported by all forest owners. Preferred target audiences should be younger people with a view to make them aware that orderly forest development is essential to their future well-being, especially when practised on forest lands located closer to them all over the country.

Approaches such as that of the Northern Forest Products Association of B.C., which involves high school students in association meetings, are the way to go. Other examples, like the big multimedia campaign launched recently by the Florida Forestry Association with the theme of "Florida Forests Forever", are very impressive and will no doubt give positive results.

The whole exercise will have been successful only when most people favor forest development rather than oppose it (Paillé
1987). This is the case now in some countries like Sweden, but not yet in Canada.

\section{Prioritizing the Development of Private Forests}

\author{
"The crucial task is to balance the need to exploit forests \\ against the need to preserve them" \\ The Brundtland Report (WCED 1987))
}

I believe that the second largest challenge facing the Canadian forest sector is the prioritization for development and management of forest lands that are located closest to urban and rural centres, to major transportation facilities, to mills and wood using plants, and to trained man power. In all provinces, these are mostly private forests.

Everybody knows that human settlements occurred progressively in Canada from east to west, alongside the US border. Seigniorial properties, freehold lands, king's grants and other private tenures were attributed by the Kings of France and England or sold by the Crown along that axis mainly to favor colonization. Rail and road transportation were developed along the same axis to carry products and resources from the interior of the country to the Atlantic Ocean first, then to the Pacific Ocean.

The industrial development also occurred from east to west of Canada, first alongside the St. Lawrence River and the Great Lakes, then following the borderline with our southern neighbors. Most wood-using plants were then installed at the mouth of the largest rivers flowing toward that axis, which were used to float timber down to the mill.

Once this basic infrastructure was put into place, forest development occurred mainly in the opposite direction, going progressively from south to north or away from towns and villages, at the limit of the boreal frontier forest (Bryant et al. 1997).

I think that now is time to reverse this historical trend for several reasons:

i. while progressing towards the north, not enough attention has been put on managing southern or local forests, which in many places suffer from abuse, neglect, or a lack of investments;

ii. it has become more and more difficult to attract and retain expert manpower away from populated centres;

iii. it has become too costly to cut and bring progressively smaller and smaller trees from far away places in the north down to the mills;

iv. people have come to realize that it does not make much sense to invest in growing trees farther and farther in the north when the most productive and accessible forest lands are located close to home and to wood-using plants in the south.

Therefore, all forest stakeholders must recognize this situation as a major opportunity, and act accordingly. They must put their shoulder to the wheel in rural communities (337 of which are based solely on the forest industry), at the regional, provincial and even at the national level to convince people of the urgency of taking action to change the direction of historical forest development.

For this change to happen, most woodlot and woodland owners must change their attitude of challengers of the forest industry toward that of partners for forest development. Industrial owners of wood-using plants for their part must drop their attitude of arrogance toward woodlot and woodland 
owners, and develop the necessary links that will ensure that more wood will be grown faster, cheaper, closer to home and to mills, for the greater benefit of our society. After all, the common challenge of owners of mills and owners of lands is not to win the fight amongst themselves but, as Johnson (1997) puts it, "to convince people not only to use products made from trees, but to use more of them."

Both owners of mills and lands will also have to seek with provincial government authorities new ways of acquiring crown lands, or of integrating private and public land tenures in order to rationalize local forest management, and to make local forest development sustainable in most regions of the country. Trees don't know the difference between Crown lands and private lands, but investors and developers do.

Provincial governments of Canada for their part must recognize that private woodlands are quite often the primary sources of production of renewable natural resources (air, fruits, water, wildlife, wood), and of recreation services (climbing, cycling, fishing, hunting, observing, picking, resting, skiing, walking) located closest to populations.

They must give them a priority of utilization over Crown lands which should play a residual role everywhere.

\section{Defining Sustainable Forest Development and Implementing It}

\author{
"Sustainable development will ensure that needs of the \\ present are met without compromising the ability of future \\ generations to meet their own." \\ (The Brundtland Report (WCED 1987))
}

The third most pressing challenge in the forest sector is to define sustainable forest development in layman's terms, and to start implementing it everywhere in the country on private and public lands, with private and public funds.

In strategic direction number nine of the proposed forest strategy for 1998-2003 titled "The Global View," it is indicated that one of the critical matters that the forest sector has not yet resolved is to come up with "a common definition of sustainable forest management for all types of forests and all forest values."

If there was no success in this venture yet, it is certainly not because of a lack of effort devoted to the subject since the publication ten years ago of the World Report on Environment and Development (WCED 1987) and since the adoption in 1992 of the last forest strategy for Canada (Anon. 1997). In fact, I suggest that it is probably just the opposite: an incredibly large number of people have met on an incredibly large number of occasions to discuss a never ending list of pressing issues that must be resolved before any action can take place on the ground. The Dunsmuir III background paper (Commission on Resources and Environment 1996) is a good summary of what happened in B.C.

While some people will want to continue discussions on issues and concepts of sustainable forest management forever, those in the forest sector that are interested in acting now could borrow from the Brundtland Report (WCED 1987) a definition of sustainable forest development and "get on with the job," as we say.

The definition of sustainable forest development could be the following:

Activities aimed at the preservation and utilization of all renewable natural resources of the forest on a given territory in order to satisfy the needs and to ensure maximum short term benefits to all its present inhabitants, without compromising the ability of future generations to derive similar or increased benefits from the same territory.

Once this definition has been accepted by most forest stakeholders, the next steps would be for them to agree upon the territories over which sustainable forest development must be implemented, on forest practices codes that would guide the development, on criteria and indicators that would be used to measure the sustainability of the development, and on ways and means of involving the population in the process.

First the territory. What Canadians now want is to make sure that there will be forests forever, not only on the land they own, but also in their community and in the general area where they live. Therefore, the Defined Forest Area (DFA) on which durable forest development could be practiced and eventually certified (CSA 1996) should not be the individual private woodlot only or the individual forest management unit, but a larger area more permanently defined, such as a watershed or a county.

And for sustainability of forest development to occur over the very long term, the first thing that has to be secured is the "working forest" land base on those DFA's (Burch et al. 1995). If the general public does not care about the protection of that forest base, it will shrink inexorably like a "peau de chagrin" under pressures for conservation (Paillé 1996), and under more subtle pressures of various developments that have nothing to do with forestry, and that are consistently directed at privately owned forested lands because these lands normally are close to population centers, have less value than other cleared lands or have no designated and protected use. The biggest threat to forest land does not come from forest operations conducted with big machines like many people are lead to believe, but rather from outside the forest sector. They generally take the form of encroachments by suburban extensions, roads and power lines, extraction of nonrenewable resources, industrial parks and the like (Richards 1997). Private forest owners should be on the first line of defence. They should talk not only with government officers but with mayors, prefects, bankers, entrepreneurs and real estate developers who are in touch with those who threaten the forest land base and thus the sustainability of forest development.

Second, the forest practices codes. In many provinces, such codes have already been adopted for application on Crown forest lands following modifications in provincial forest acts aimed mostly at preserving soils, water, wildlife, scenic landscapes and the environment, and at producing social, economical, cultural, and spiritual benefits while conducting forest management operations. Most of them are now implemented on Crown lands but they are under review. By extension, some codes have been suggested for application on private forest lands but have not yet been enforced vigorously. Effective control mechanisms are needed to better monitor forest activities on private forest lands.

Third, criteria and indicators of sustainable forest management. Since the beginning of the 1990's, a tremendous activity has been supported by the Canadian Standards Association (1996) which has led to the identification of criteria that would be recognized internationally for certification of forest management (CCMF 1997) on Defined Forest Areas of Crown lands, or on individual or regrouped private forest lands. Now, 
what remains to be done essentially is for the forest industry to get on with the job of certification and do it, if the market for wood products is requesting it.

Fourth, public involvement in forest development. Here also several recipes have been tried since the early 1990 s (Duinker and Euler 1997) and most are not really convincing, mainly for lack of experience on the part of developers rather than lack of public interest. Simplified notions and documents must be prepared for examination by forest owners, residents, interested publics and the general public, and some methods must be elaborated to ensure their involvement not only at the planning stage but also at the decision-making level, at the execution stage and at time of final review. Referendums could be used for testing preferred development hypotheses as is common practice in Switzerland, for example. Governments at all levels should have a mandate to create the proper climate for orderly development of all forest resources on private and Crown lands, for the greater benefit of license holders, land owners, taxpayers, and shareholders alike.

\section{Convincing Forest Land Owners to Invest More in Forest Resources Development}

\author{
"We have to produce more wood to help solve \\ environmental problems" \\ (Johnson 1997)
}

A fourth challenge for stakeholders of the forest sector is to convince all private woodland owners to invest much more attention, time, effort and even money in growing more wood and in offering more services on their properties.

Too many landlords in Canada still take forest lands and forest stands for granted, and do not consider it necessary to do much more than enjoy their presence or harvest what they need from them, and let them grow by themselves. Quite often, they even consider after tax revenues as profits that they can invest in anything else but growing trees.

Based on projections of future demand for wood, and on the pressures that are likely to be applied on private woodlands as the population grows and as this strategy is implemented, land owners should set their expectations much higher, and, depending on the location of their property, on the land use plan for it, and on its productive capacity, should decide to climb the following silvicultural stairway.

A first step would be for most forest owners to increase the attention given to each and every hectare of productive or potentially productive land on their property, and make sure that it is continually in a state of production of some potentially useful renewable resource.

A second step would be for many forest owners to practice what one might call good forest husbandry, making sure that their property is well delineated, that it is made completely accessible, and then seeing to it that it is properly protected while being tended to avoid losses of useful material through natural mortality or predators.

A third step would be for some forest owners to practice intensive silviculture, choosing whatever treatment to educate forest stands that would maximize wood production at the lowest cost possible. At this stage, forest owners could also put abandoned farm lands (if there is any) back into forest production in order to help store more carbon (Guy and Benowicz 1998), or for some other reason, and even plan to recuperate some mar- ginally productive land through drainage or other appropriate techniques.

A fourth and last step would be to intensively cultivate forest lands in order to produce crops on a very short rotation. Not only should forest land owners invest more in producing wood, but they should also try growing new plants, or using their lands for new recreation activities in order to capture more $\mathrm{CO}_{2}$ and to maximize the revenue base of each piece of their properties.

If the forest sector was successful in making all 425,000 private forest owners of Canada decide to at least begin climbing the silvicultural stair described above, it should be possible to substantially increase wood fiber production over and above the present level of 40 million cubic meters a year, and it would benefit most communities where these lands are located, especially in provinces or regions where private holdings are more important than Crown lands.

A major incentive to woodland owners for climbing the stairway faster would be for governments to begin or to continue supporting part of the silvicultural costs for growing wood, and to allow for a write off from annual revenues of the portion of silvicultural costs that is supported by the land owner.

\section{Convincing all Governments to Invest More in Sustainable Forest Development}

"Sustainable development is not a fixed state of harmony but rather a process of change in which the exploitation of resources, the direction of investments, the orientation of technological development, and institutional change are made consistent with future as well as present needs"

(The Brundtland Report (WCED 1987))

While forest land owners invest more and more time, efforts and money in growing trees, all orders of government should consolidate their capability of offering their help and services to these owners; governments should invest more in the conduct of activities related to forest development that forest owners cannot or should not assume alone.

Convincing governments to do that is quite a challenge because traditionally they have spent only little money in the public forest sector (let alone the private one) in comparison to their revenues; unless all forest stakeholders work hand in hand to ensure the sustainability of the forest, this situation will not change. We are talking here about expenses necessary to ensure that an economic activity worth more than $\$ 70$ billion a year (Ressources Naturelles Canada 1997) can be maintained or expanded; this is the annual value of shipments of all Canadian wood using plants, $20 \%$ of which is extracted from private woodlands.

Some potential fields of support are suggested hereafter:

The federal government, for example, could invest much more in market research, and in the reduction of non-tariff barriers to international trade of forest products.

Federal/provincial agreements could be renewed to better support private woodland resource inventories and mapping comparable to what is done on Crown lands, mechanization of forest work, operations research, transfer of technology, and fiscal incentives to growing trees. Investments in silvicultural treatments should also be considered partly as a correction of past mistakes, and supported by both provincial and federal governments. The rest could be considered as an investment in the education of forest owners who, until fairly recently, were 
never told too much about good forest husbandry, or how to grow more wood for today and for tomorrow; this part could be supported by provincial governments.

Provincial goverments could also, for example, improve substantially their contribution to the technical education of forest workers, to supporting research and development on value added to forest materials, to financial management of private woodlands, and to the creation and stabilization of jobs in rural communities.

Regional and municipal governments could help woodland owners improve forest development substantially in the fields of taxation, resource allocation, licensing of various land uses, regional planning of forest activities, and possibly certification of forest management.

\section{Conclusion}

In conclusion, at the beginning of the XXI century, we have to take private land forestry out of its marginality, and make it a figurehead, a national pride in honor of its 425,000 owners, in honor of all the industries thriving on it, in honor of all those who find work and leisure in it, and in honor of the Canadian population getting economic benefits derived from the activity that it generates.

We have to stop viewing the private forest sector merely as a bunch of farmers selling four-foot pulpwood to pulp and paper companies through their marketing boards.

We have to stop viewing private forests merely as places where you can cut your own firewood, produce your maple syrup and grow some Christmas trees.

We have to support certifiable developments in the private forest sector of our economy. We have to make sure that more wood is grown faster, cheaper and closer to our homes and mills, on a stable land base, in accordance with sound forest practices codes, and with full public involvement. Forest land owners must invest more attention, more time, more effort and more money on their properties, climb the silvicultural stairway, and thus make the forest industry benefit more in provinces and regions where private holdings are more important. Governments must also invest more in sustainable forest development, recognizing that private forest lands are the primary source of production of renewable natural resources, and of recreation services located closest to population centers.

When the five challenges described in this paper have been properly dealt with by a majority of private forest land owners, by most forest companies and by governments at all levels, the strategy will have contributed to making sustainable forest development a reality in this country.

\section{References}

Anon. 1997. Stratégie nationale sur les forêts-Durabilité des forêts: un engagement canadien- Rapport d'évaluation finale, pour la Coalition pour la Stratégie Nationale sur les Forêts. Groupe sélect présidé par Dr. G. Baskerville. Ottawa.

Bryant, D. et al. 1997. The Last Frontier: Ecosystems \& Economies on the Edge. World Resources Institute, New York. 42 pp.

Burch et al. 1995. The Working Forest of British Columbia. Madeira Park, BC. 167 pp.

Canadian Council of Forest Ministers. 1998. National Forest Strategy (1998-2003) Sustainable Forests: A Canadian Commitment (Draft II), Natural Resources Canada. 49 p.

Canadian Standards Association. 1996. A Sustainable Forest Management System: Guidance Document. Ottawa. 32 pp.

Commission on Resources and Environment. 1996. On the Road to Sustainability - A Synopsis of Provincial Sustainability Initiatives. Dunsmuir III Background Paper. Victoria. 145 pp.

Conseil canadien des ministres des forêts. 1997. Critères et indicateurs de l'aménagement durable des forêts. Ressources naturelles Canada. Ottawa. 51 pp.

Duinker, P.N. and D.L. Euler. 1997. Les enjeux forestiers au Canada. Faculté de foresterie, Université Lakehead, Thunder Bay. 20 p. Guy, R.D. and A. Benowicz. 1998. Can Afforestation Contribute to a Reduction in Canada's Net $\mathrm{CO}^{2}$ Emissions? Department of Forest Sciences, Faculty of Forestry, University of British Columbia. 21 p. Johnson, N.E. 1997. Trees, Past, Present and Future - Key to Sustainability in Managing the Resources of the World's Forests, Stockholm, The Marcus Wallenberg Foundation Symposia Proceedings: $11.96 \mathrm{p}$.

May, E. 1998. At the Cutting Edge - The Crisis in Canada's Forests. Key Porter Books Ltd., Toronto. 294 p.

Paillé, G.G. 1987. Les principaux éléments d'une stratégie forestière pour le Canada. Québec, Forêt Conservation 53(9): 114-119.

Paillé, G.G. 1996. D'hier vers demain dans le secteur forestier au Québec. Mont Ste-Anne, Assemblée annuelle, Ordre des ingénieurs forestiers du Québec.

Paillé, G.G. 1997. La forêt privée du Québec comme source d'approvisionnement des usines de transformation du bois pour le futur, Roberval, Assemblée annuelle, Regroupement des Sociétés d'Aménagement Forestier du Québec.

Ressources Naturelles Canada. 1997. L'état des forêts au Canada 1996-1997 les leçons du passé. Ottawa. 126 p.

Richards, G.R. 1997. Managing Change Strategies for Future Challenges in the Forest Industry. Faculty of Agriculture, Forestry and Home Economics, University of Alberta. Forest Industry Lecture No. 38. Edmonton.

World Commission on Environment and Development. 1987. Our Common Future. Oxford University Press. Oxford. 400 p. 